\title{
Involvement of plasma adipokines in metabolic and reproductive parameters in Holstein dairy cows fed with diets with differing energy levels
}

\author{
N. Mellouk, ${ }^{*}$ C. Rame, ${ }^{*}$ J. L. Touzé, ${ }^{*} E$. Briant, $\dagger$ L. Ma, ${ }^{*}$ D. Guillaume, ${ }^{*}$ D. Lomet, ${ }^{*}$ A. Caraty, ${ }^{*}$ T. Ntallaris,‡ \\ P. Humblot, $\ddagger$ and J. Dupont ${ }^{* 1}$ \\ *INRA UMR85 Physiologie de la Reproduction et des Comportements, F-37380 Nouzilly, France; CNRS UMR7247 Physiologie \\ de la Reproduction et des Comportements, F-37380 Nouzilly, France; Université François Rabelais de Tours, F-37041 Tours, France; IFCE, \\ F-37380 Nouzilly, France \\ †INRA, UEPAO 1297, F-37380 Nouzilly, France \\ †Division of Reproduction, Department of Clinical Sciences, Swedish University of Agricultural Sciences (SLU), Uppsala, Sweden 75103
}

\begin{abstract}
This study aimed to investigate the association between plasma adipokine concentrations and metabolic and reproductive parameters in Holstein dairy cows fed diets with different energy levels during the peripartum period. The experiment started 1 mo before first calving and was maintained for 2 lactations. Dry matter intake and energy balance in animals fed a lowenergy (LE) diet were significantly lower than that of animals fed a high-energy (HE) diet in the first lactation. Body weight, milk production, back fat thickness, and plasma concentrations of fatty acids, glucose, and insulin were not affected by diet, whereas plasma leptin and adiponectin concentrations were lower and plasma resistin concentrations higher in animals fed the LE diet. Unlike concentrations of adiponectin, plasma resistin concentrations were positively correlated with back fat thickness and plasma fatty acids concentrations and negatively correlated with dry matter intake and plasma leptin concentrations. No effect of diet was found on reproductive variables; that is, pregnancy rates at 35 or $90 \mathrm{~d}$ after artificial insemination (AI); numbers of small $(3-5 \mathrm{~mm})$, medium $(>5$ and $\leq 7 \mathrm{~mm})$, and large $(>7 \mathrm{~mm})$ follicles; calving-to-AI and calvingto-calving intervals; and magnitude and duration of the LH surge. However, the commencement of luteal activity after first calving occurred sooner and the frequency of LH pulses was higher in the HE group than in the LE group. A significant positive correlation was found between the number of follicles (of any size) and the area under the curve of plasma resistin concentrations. The number of small follicles was also positively correlated with the nadir of plasma resistin concentrations. Taken together, these results suggest that dietary energy content in the range applied here can alter the resumption
\end{abstract}

Received January 29, 2017.

Accepted June 19, 2017.

${ }^{1}$ Corresponding author: joelle.dupont@inra.fr of ovarian activity and LH pulsatility without affecting fat mobilization. Plasma adipokine profiles (leptin, resistin, and adiponectin) were significantly altered by diet and negative energy balance but relationships with reproductive variables were limited to follicular growth characteristics and plasma resistin concentrations.

Key words: diet, metabolism, adipokines, fertility

\section{INTRODUCTION}

In the last 5 decades, intensive genetic selection for milk production has resulted in a modern dairy cow with very high milk yield potential but reduced fertility (Royal et al., 2000; Lucy, 2001; Dobson et al., 2007). Considerable scientific evidence supports the view that infertility is influenced by nutrition (Garnsworthy et al., 2008; Friggens et al., 2010). High-yielding dairy cows enter a status of negative energy balance (NEB) around calving when the energy demand for maintenance and lactation exceeds dietary energy intake (Bauman and Currie, 1980). Negative energy balance results in mobilization of body tissue reserves, which can impair reproductive performance (Butler, 2000). The fact that prolonged anestrus during the postpartum period results in compromised subsequent reproductive performance emphasizes the importance of exploring the relationships that exist between nutritional status and early resumption of ovarian cyclicity. Several studies have shown the negative effects of NEB on in vitro oocyte maturation (Leroy et al., 2006), the oviduct (Fenwick et al., 2008), and the endometrium (Llewellyn et al., 2008; Wathes et al., 2011; Valour et al., 2013). However, despite the positive roles of LH on follicular growth, oocyte maturation, and ovulation (Diskin et al., 2003), limited information exists about the effect of diet on LH secretion. Negative energy balance in early lactation is also associated with changes in several key metabolic hormones, such as insulin (Coyral-Castel et al., 2013; Ntallaris et al., 2017), and adipokines, including leptin (Liefers et al., 2003; Sadri et al., 2011), 
adiponectin (Giesy et al., 2012; Ohtani et al., 2012), and resistin (Reverchon et al., 2014a). It is well known that the expression and secretion of leptin are correlated with body fat mass and affected by changes in feed intake (for review, see Zieba et al., 2005). In the dairy cow, plasma adiponectin is negatively correlated with empty BW, back fat thickness, and adipose tissue mass (Singh et al., 2014; De Koster et al., 2017). Furthermore, plasma resistin levels are highly correlated with fatty acid mobilization, DMI, and energy balance (Reverchon et al., 2014b).

Recently, the expression of leptin (Madeja et al., 2009), adiponectin (Lagaly et al., 2008; Maillard et al., 2010), and resistin (Maillard et al., 2011; Spicer et al., 2011) were documented in ovarian cells, including oocytes, granulosa, and theca cells. In vitro, these adipokines modulate ovarian steroidogenesis in dairy cows (Spicer et al., 2000, 2011; Maillard et al., 2011). Furthermore, adiponectin regulates also oocyte maturation and early embryo development in different species (Chappaz et al., 2008; Richards et al., 2012) and mice defective for adiponectin gene are infertile due to ovarian dysfunctions (Cheng et al., 2016). In dairy cows, greater concentrations of leptin are associated with either longer calving-to-conception intervals (Wathes et al., 2007a) or shorter intervals to first observed estrus (Liefers et al., 2003). However, a decrease in circulating adiponectin is related to delayed and abnormal luteal activity in lactating postpartum Holstein cows (Kafi et al., 2015). Variations in mRNA expression of adiponectin and its receptor, AdipoR2, in adipose tissue collected in postpartum cows in NEB have been associated with one fertility QTL (Elis et al., 2013). However, even though these adipokines are key players in the regulation of energy metabolism and reproductive functions in rodents and human, their roles in the interactions between energy balance and reproduction need to be clarified.

In the present study, we hypothesize that circulating adipokines could be modulated by the energy components of the diet and could be associated with variations in reproductive parameters related to low fat mobilization. The objectives of this present study were to investigate the effects of high- and low-energy diets on metabolic parameters, including cytokines, and to investigate their possible effect on reproductive function in first- and second-lactation Holstein dairy cows.

\section{MATERIALS AND METHODS}

\section{Ethics}

An ethics committee (Comité d'Ethique en Expérimentation Animale Val de Loire, CEEA VdL, protocol reference number 2012-10-4) approved all experimental protocols, which were consistent with the guidelines provided by the French Council for Animal Care.

\section{Animals}

The study took place at the experimental unit UEPAO (Institut National de la Recherche Agronomique, Nouzilly, France) between September 2012 and January 2015. Thirty-nine pregnant Holstein heifers were distributed in 2 dietary treatments groups according to back fat thickness measurement. All animals were managed in a straw-bedded yard. All observations, sampling, and data registration took place during the animals' first and second lactations. Animals were fed either a highenergy (HE) diet calculated to yield $35 \mathrm{~kg}$ of milk/cow per day $(\mathrm{n}=17)$ or a low-energy $(\mathbf{L E})$ diet calculated to yield $25 \mathrm{~kg}$ of milk/cow per day $(\mathrm{n}=22$; Figure 1). The diets started from 1 mo before the presumed first calving date and then applied during 2 lactations. The compositions of $\mathrm{HE}$ and LE diets are shown in Table 1 (diets calculated according to the INRA French feeding system; INRA, 2007). Animals were artificially inseminated from 55 to $60 \mathrm{~d}$ postpartum $12 \mathrm{~h}$ after heat detection with the semen of the same bull. Cows were re-inseminated until they became pregnant. From the 39 animals studied during their first lactation, 35 were studied during their second lactation (2 nonpregnant cows were excluded, and 2 cows died for reasons unrelated to the study).

\section{Live BW, Variation in Empty BW, Milk Yield, and DMI}

During the dry period, animals were kept in groups in loose housing where the total DMI from feed was estimated from the given amount. The animal housing was not equipped with defined feeders, so it was not possible to determine energy balance (EB) during this period. After calving, cows were milked twice daily and weighed automatically after each milking (software RIC version RW1.7). Only live BW (LBW) data measured following morning milking were used in subsequent analyses because the afternoon LBW showed high variation. As LBW is affected by digestive contents, the estimation of empty BW was corrected for digestive tract contents. A change of $4.5 \mathrm{~kg}$ of digestive contents per $\mathrm{kg}$ of DMI was assumed (Rémond, 1988). Variation of empty BW (VEBW) was calculated every day: $\mathrm{EBW}$ of the previous day was taken as the reference weight (Coyral-Castel et al., 2013). Live body weight and VEBW (compared with 1 mo before calving) were measured from -4 to 8 wk peripartum (wkpp) in females during their first and second lactations. All cows 
Table 1. Composition of the high-energy (HE) and low-energy (LE) diets (\% of DM) and chemical composition and nutritional value of feeds $(\mathrm{g} / \mathrm{kg}$ of DM unless otherwise noted)

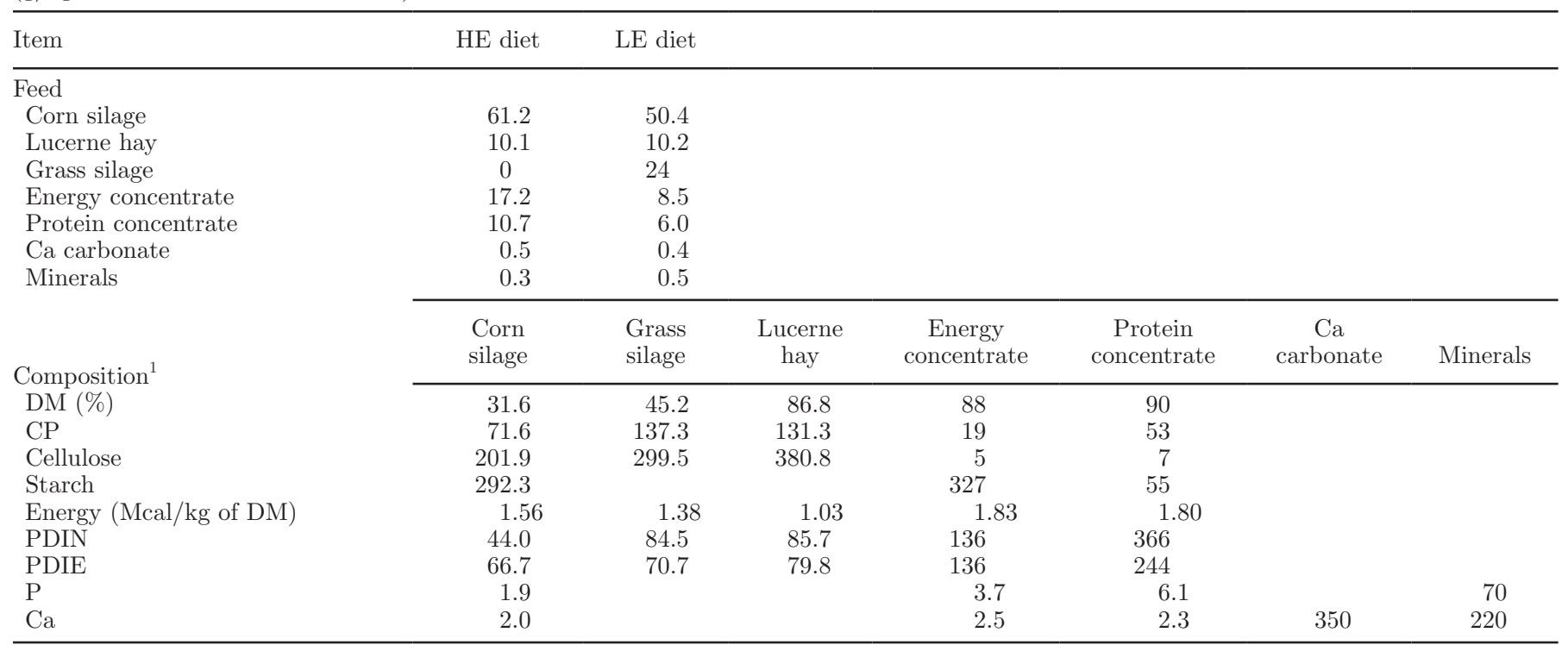

${ }^{1} \mathrm{PDIN}=$ protein digested in the small intestine supplied by rumen-undegraded dietary protein and by microbial protein from rumen-degraded dietary nitrogen; PDIE = protein digested in the small intestine supplied by rumen-undegraded dietary protein and by microbial protein from rumen-fermented OM (INRA, 2007).

were milked twice daily. At the entrance of the milking parlor, cows were identified by an electronic collar, and milk yield (MY) of each cow was automatically recorded (software R-Manufeed 500 pro, vc5 version 2.011.14, 1996, Manus-Delaval, Elancourt, France). Energy-corrected milk (4\% fat, $3.3 \%$ protein) was calculated according to the following equation: $\mathrm{ECM}=$ (milk production $\times 0.383 \times$ fat $\%+$ milk production $\times$ $0.242 \times$ protein $\%+0.7832 \times$ milk production $/ 3.1138$ ). Dry matter intake was determined from the intake of fresh matter and the DM content of each feed of the ration. The diet was distributed twice daily, at 0900 and $1500 \mathrm{~h}$, and each cow had access to several feeders
(Insentec B.V., Marknesse, the Netherlands). On average, there was 1 feeder for 2 cows. When a cow arrived in front of the feeder, it was recognized by a unique passive transponder attached to her ear tag. If the cows were allowed, the feeder opened and the quantity of food eaten was automatically recorded (RIC software, version RW1.7, Incentec, Marknesse, the Netherlands). Animals had access to their diet at all times. Dry matter intake was calculated daily for the HE (calculated to provide $35 \mathrm{~kg}$ of milk/cow per day) and LE (calculated to provide $25 \mathrm{~kg}$ of milk/cow per day) diets, from calving to 8 wkpp. The chemical composition of each feed is shown in Table 1. The nutritional values of the

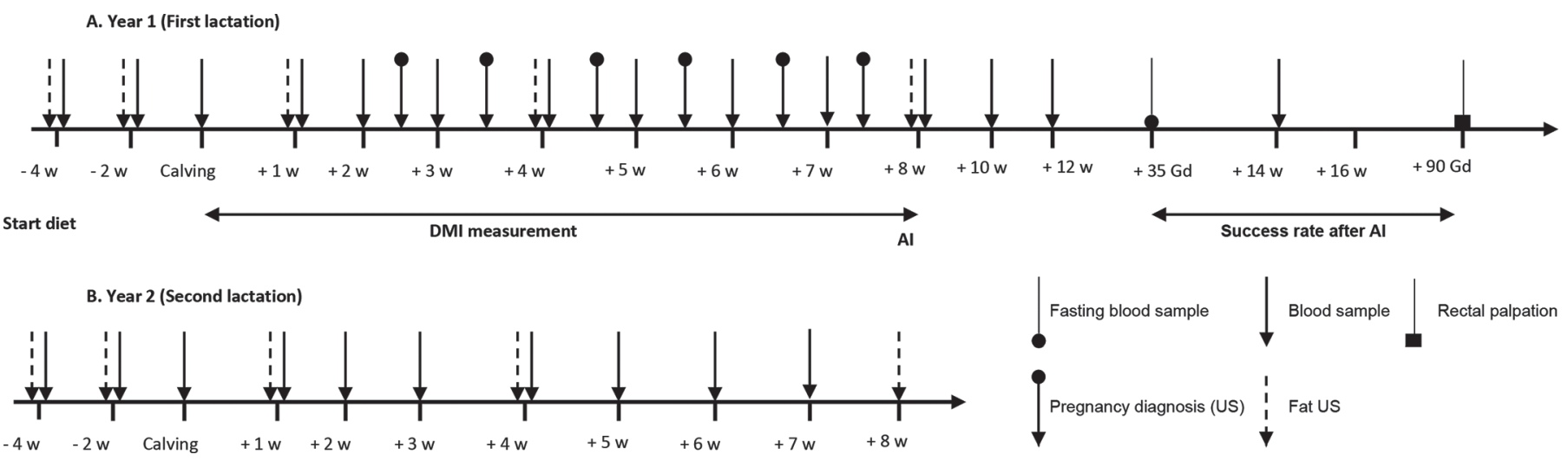

Figure 1. Description of the timing for blood samples, ovarian ultrasound, and fertility measurements for the peripartum period during year 1 or first lactation (A) and year 2 or second lactation (B) of primiparous Holstein dairy cows fed with either a high-energy (HE) or a low-energy (LE) diet. $\mathrm{w}=$ week peripartum, Gd = gestational day, $\mathrm{AI}=$ first $\mathrm{AI}, \mathrm{US}=$ ultrasound. 
different ingredients in the diets were available from chemical analysis. Energy balance (Mcal/d) was calculated during the lactating period only (from calving to 8 wkpp), as it was not possible to measure DMI during the dry period. It was calculated per week according to the INRA feeding system (INRA, 2007) as the difference between energy intake and energy requirements for maintenance, MY, and pregnancy. Animals were not pregnant during the studied period. According to the INRA system, the daily requirement for maintenance is $1.1 \times 0.041 \times \mathrm{kg}^{0.75}$, and the requirement for $\mathrm{MY}$ is $0.44 \times \mathrm{MY}$. Energy intake and $\mathrm{EB}$ are expressed in Megacalories per day, where $\mathrm{kg}^{0.75}$ indicates metabolic BW (INRA, 2007).

\section{Subcutaneous Adipose Tissue Thickness}

Adipose tissue mobilization was assessed through subcutaneous fat thickness measurements in the sacral region using ultrasonographic examination with a linear probe (LA 332 3.5/10.0-MHz transducer; Mylab30vet; R-Esaote, Hospimedi, Saint-Crépin-Ibouvillers, France), as previously described (Schröder and Staufenbiel, 2006). In both lactations, back fat thickness was determined at -4 and -2 wkpp and 1,4 , and 8 wkpp (Figure 1A and B).

\section{Plasma Metabolites}

Blood samples were taken from coccygeal vein on heparinized Vacutainers (Dutcher, Brumath, France) before diet distribution, once every 2 wk from 1 mo before calving until calving and then weekly from calving to 8 wkpp (Figure 1A and B). Blood was immediately centrifuged $\left(2,000 \times g\right.$ for 15 min at $\left.4^{\circ} \mathrm{C}\right)$ and the separated plasma was stored at $-20^{\circ} \mathrm{C}$ until assay. Fatty acids and glucose were determined by enzymatic colorimetry assays (Wako Chemicals GmbH, Neuss, Germany; Sigma Aldrich, Saint Quentin-Fallavier, France). The intra- and interassay coefficients of variation $(\mathbf{C V})$ of both plasma fatty acids and glucose measures were 6 and 7.8, respectively.. Plasma insulin was measured by RIA from $100 \mu \mathrm{L}$ of undiluted plasma as previously described (Salazar-Ortiz et al., 2011). Plasma fatty acids, glucose, and insulin concentrations were recorded from -4 to 7 wkpp (first and second lactations). Plasma bovine resistin concentration was determined with a commercially available bovine resistin ELISA (E90847Bo, USCNLife/Cloud Clone Corp., Houston, TX), according to the manufacturer's protocol, with intra- and interassay CV of 5.6 and $6.0 \%$, respectively. Plasma bovine total adiponectin and leptin concentrations were analyzed by using ELISA kits (E11A0125 and E11L0038; Holzel Diagnostika, Köln, Germany), with intra- and interassay CV $<8 \%$ (leptin: intraassay $=6.5 \%$ and interassay $=8 \%$; adiponectin: intraassay $=6 \%$ and interassay $=6.2 \%$ ). Plasma leptin, resistin, and adiponectin concentrations were assessed from -4 to 7 wkpp in first and second lactations. Plasma progesterone was analyzed using an ELISA (Canepa et al., 2008) from $10 \mu \mathrm{L}$ of undiluted plasma on samples collected 3 times a week from 15 wkpp to the first AI with the detection limit of the assay being $0.4 \mathrm{ng} / \mathrm{mL}$. The intra- and interassay $\mathrm{CV}$ of plasma progesterone were 5 and $6 \%$, respectively.

\section{LH and Anti-Müllerian Hormone Assays}

Plasma LH concentrations were measured using a previously described RIA (Pelletier et al., 1968, Montgomery et al., 1985). Bovine LH standard preparations (NIH-LH-B4; National Hormone and Peptide Program, Torrance, CA) were used. The inter- and intraassay CV for 4 assays were 7.5 and $7.4 \%$, respectively, and assay sensitivity was $0.15 \mathrm{ng} / \mathrm{mL}$ relative to a standard, 1055-CY-LH, which is equivalent to $0.31 \mathrm{NIH} \mathrm{LH-S1}$ (an LH standard). Plasma anti-müllerian hormone (AMH, a plasma marker of ovarian follicle reserves) was measured with a specific bovine AMH ELISA kit from Antibodies-Online (ABIN456868, Eurogentec, Seraing, Belgium) from blood samples collected at 1 wkpp (in lactation 1). The intra- and interassay $\mathrm{CV}$ were 7 and $9 \%$, respectively. The concentration of AMH was measured in $50 \mu \mathrm{L}$ of undiluted plasma from animals after first calving. In all plasma samples, AMH concentrations exceeded the detection limit of the assay (0.5 $\mathrm{ng} / \mathrm{mL})$.

\section{Ovarian Ultrasonographic Examinations of the Cycle Before Al}

Ovarian follicular dynamics of primiparous cows ( $\mathrm{n}=$ 17 and $\mathrm{n}=22$ for HE and LE groups, respectively) were monitored during the cycle before AI, 3 times a week (Figure 1A) by transrectal ultrasonography using a linear probe (LV 513 6.0/8.0-MHz transducer; Mylab30; Esaote) allowing detection and measurement of antral follicles. Follicles with diameters from 3 to $5 \mathrm{~mm}$, from 5 to $7 \mathrm{~mm}$, or greater than $7 \mathrm{~mm}$ were counted. Based on these observations, the growth of each follicle was followed and the number of follicular waves was determined as described by Sirois and Fortune (1988). The length of the cycle was calculated while combining the results from ovarian scans and data from estrus detection. The beginning of the cycle was defined as the day of estrus detection and confirmed by ovulation. In case of silent ovulation, the beginning of the cycle was defined as the day when the dominant follicle of 


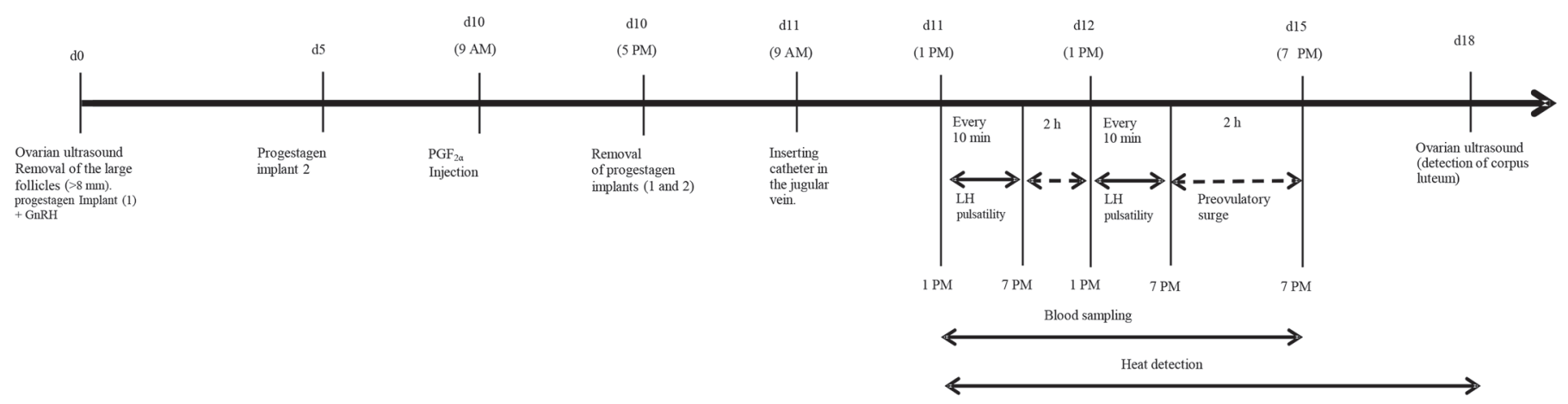

Figure 2. Experimental design and blood sampling timelines for LH pulsatility and LH preovulatory surge experiments performed on both high-energy (HE) and low-energy (LE) diet groups of animals during years 1 and 2.

the ovulatory wave reached its maximal size before an ovulation was detected. The end of the cycle was the day of AI determined by estrus detection. After AI, ovulation was confirmed by measuring progesterone 3 times a wk until $21 \mathrm{~d}$ post-AI (information not provided in Figure 1). Ovarian follicles were classified according to their diameter: small (SF, 3-5 mm), medium (MF, $>5$ and $\leq 7 \mathrm{~mm}$ ) and large (LF, $>7 \mathrm{~mm})$, and counted. The mean number of follicles in each class per cow was calculated from the total number of follicles of a given class from both ovaries (SF, MF, or LF) divided by the number of ultrasonographic examinations.

\section{LH Pulsatility and Occurrence of Preovulatory Surges}

Between 20 and $60 \mathrm{~d}$ after first calving, LH profiles were determined from $11 \mathrm{HE}$ and $12 \mathrm{LE}$ primiparous cows to characterize the pulsatility and preovulatory LH surges at time of first ovulation. Only data from animals for which a LH peak was observed were retained for analysis. As shown in Figure 2, the protocol to study LH secretion profiles required the use of estrus synchronization. A subcutaneous progestogen ear implant (Crestar N.D., norgestomet, $3.3 \mathrm{mg} / \mathrm{cow}$, MSD Animal Health, Intervet, Beaucouzé, France) was inserted and 2 i.m. injections of a synthetic $\mathrm{GnRH}$ analog (Receptal N. D., buserelin acetate, $0.4 \mathrm{mg} / \mathrm{cow}$, MSD Animal Health) were administered at $0 \mathrm{~d}$ (time of implant insertion) and $5 \mathrm{~d}$. At $0 \mathrm{~d}$, the largest follicle was removed (>8 mm, Figure 2). Ear implants were removed by $10 \mathrm{~d}$ and an i.m injection of $\mathrm{PGF}_{2 \alpha}$ analog, (Prosolvin N.D., luprostiol, $15 \mathrm{mg} / \mathrm{cow}$, Virbac, Carros, France) was administered to induce corpus luteum regression. On the morning of $\mathrm{d} 10$, animals were cannulated with a 2-mm-diameter catheter placed in the jugular vein under local anesthesia with lidocaine at several points $(5 \mathrm{~mL}$, Lurocaïne, Vetoquinol, Lure Cedex, France). The cows were restrained during catheter insertion, and catheters were held in place during the sampling period with adhesive tape. After each sample, the catheters were rinsed with a few milliliters of heparinized sterile saline solution. Twenty hours after the removal of progestogen implant, LH secretion profiles were determined from samples taken every $10 \mathrm{~min}$ for $6 \mathrm{~h}$ (to characterize LH pulsatility) and every $2 \mathrm{~h}$ for $113 \mathrm{~h}$ (to study the preovulatory LH peak). At the end of $113 \mathrm{~h}$, the catheters were removed and the animals were submitted during the following $7 \mathrm{~d}$ to daily blood sampling from the coccygeal vein to measure circulating progesterone concentrations of the newly formed corpus luteum. Luteinizing hormone pulsatility was characterized from a software version based on use of the DynPeak algorithm (Vidal et al., 2012). The duration of the preovulatory LH surge was defined as the interval from time that serum LH concentrations exceeded $1 \mathrm{ng} / \mathrm{mL}$ (baseline) until serum LH declined to $<1 \mathrm{ng} / \mathrm{mL}$ after an LH peak was observed.

\section{Reproductive Parameters}

Postpartum commencement of luteal activity (C-LA) was defined as the first day that the plasma progesterone concentration was $>0.70 \mathrm{ng} / \mathrm{mL}$. This threshold was defined from our full data set as the value at which $95 \%$ of the minimum concentrations flanking the supposed day of estrus were higher than this concentration. The pregnancy rate was determined twice after AI: on $35 \mathrm{~d}$ by ultrasonographic examination and on $90 \mathrm{~d}$ by transrectal palpation. Pregnancy rate was calculated as the number of pregnant females divided by the total number of inseminated females.

\section{Statistical Analyses}

All statistical analyses were performed with SAS software (version 9.3; SAS Institute Inc., Cary, NC). If not specified, data were analyzed using the MIXED 
procedure for linear mixed models. We included "cow" as a random effect but then the estimated $\mathbf{G}$ matrix was not positive so it was removed from the final model. A repeated effect of time (week pre- or postpartum) within animals was tested. The correlations between test days were accounted for by specifying a correlation structure (spatial power) among residuals to consider that time intervals between samplings were not exactly the same.

The residuals from the observations generated from the mixed models were tested for normal distribution. Data on blood metabolite concentrations (glucose, insulin, fatty acids), C-LA, cycle length, and follicle size (SF, MF, and LF) deviated from a normal distribution and were log-transformed. However, to improve clarity and avoid redundancy, the respective log-transformed values are referred to as glucose, insulin, fatty acids, C-LA, cycle length, and follicle size (SF, MF, and LF) throughout the paper.

The model used was

$$
\begin{aligned}
\mathrm{Y}_{\mathrm{ijkl}}=\mu+ & \operatorname{Diet}_{\mathrm{i}}+\mathrm{Wk}_{\mathrm{j}}+\mathrm{Yr}_{\mathrm{k}}+\operatorname{Diet}_{\mathrm{i}} \times \mathrm{Yr}_{\mathrm{k}} \\
& +\operatorname{Diet}_{\mathrm{i}} \times \mathrm{Wk}_{\mathrm{j}}+\mathrm{e}_{\mathrm{ijk} \mathrm{l}},
\end{aligned}
$$

where $Y_{\mathrm{ijkl}}$ is the dependent variable (DMI, EB, LBW, VEBW, MY, ECM, glucose, insulin, fatty acids, leptin, adiponectin, resistin); $\mu$ is the overall mean; Diet is $_{i}$ the fixed effect of diet $\mathrm{i}(\mathrm{i}=\mathrm{HE}, \mathrm{LE}) ; \mathrm{Wk}_{\mathrm{j}}$ is the fixed effect of week $\mathrm{j}$ ( $\mathrm{j}=9$ classes, 11 classes); $\mathrm{Yr}_{\mathrm{k}}$ is the fixed effect of lactation $\mathrm{k}(\mathrm{k}=1,2)$; Diet $_{\mathrm{i}} \times \mathrm{Yr}_{\mathrm{k}}$ is the interaction between Diet ${ }_{\mathrm{i}}$ and $\mathrm{Yr}_{\mathrm{k}}$; Diet $_{\mathrm{i}} \times \mathrm{Wk}_{\mathrm{j}}$ is the interaction between Diet $_{i}$ and $\mathrm{Wk}_{\mathrm{j}}$; and $\mathrm{e}_{\mathrm{ijkl}}$ is the residual error.

Least squares means ( $\mathrm{LSM} \pm \mathrm{SEM}$ ) estimated by the models were adjusted using the Scheffé adjustment for multiple post-ANOVA comparisons and compared.

Reproductive data (C-LA, cycle length, number of follicular waves, number of follicles, interval from calving to first AI, and calving-to-calving interval) were analyzed using the MIXED procedure for linear mixed models. The model included the fixed effect of diet, year (when applicable), and the diet $\times$ year interaction.

Data corresponding to binary variables (follicular waves, pregnancy rates on $35 \mathrm{~d}$ or $90 \mathrm{~d}$ at first AI, \% pregnant at first AI) were analyzed using the GENMOD procedure in SAS. The model included the fixed effect of diet. The GLM parameterization of CLASS variables and the logit option statement were used.

The area under the curve (AUC) of plasma adipokine concentrations was performed as the sum of linear AUC that was calculated according to the following formula: $\mathrm{AUC}=\mathrm{x}(\mathrm{t} 1)+\mathrm{y}(\mathrm{t} 2) \times 2 /(\mathrm{t} 2-\mathrm{t} 1)$ with $\mathrm{x}$ and $\mathrm{y}$ as a value of plasma adipokine concentration at 2 times (t1 or t2). The multivariate ANOVA (MANOVA) option was used in the multivariate GLM model to calculate and measure the strength and direction of associations that exist between variables measured. The model included the fixed effects of diet, year, and the interaction between diet and year. Differences with $P \leq$ 0.05 were considered significant.

\section{RESULTS}

\section{Live BW and VEBW in the Peripartum Period in Heifers and Primiparous Dairy Cows}

Live BW was affected by week and year $(P \leq 0.0001)$, whereas no significant effect of diet was observed (Figure 3A). However, a significant effect of diet was found (difference LE - HE, $-1.7 \mathrm{~kg} / \mathrm{d}$ in lactation 1 and -1.9 $\mathrm{kg} / \mathrm{d}$ in lactation $2 ; P=0.05)$ on $\operatorname{VEBW}(\mathrm{kg} / \mathrm{d})$ and the year effect was not significant (Table 2, Figure 3B). During the 2 lactations, LBW and VEBW decreased from -2 to 8 wkpp $(P \leq 0.0001$; Figure $3 \mathrm{~A}$ and $\mathrm{B})$.

\section{MY, ECM Yield, DMI, and Energy Balance at the Beginning of First and Second Lactations}

As shown in Figure 3C and D, MY and ECM were not affected by the diet, whereas a time (week and year, $P<0.0001$ ) effect was observed for these 2 parameters. However, a significant effect of diet was found on DMI (difference HE - LE: $1.8 \mathrm{~kg} / \mathrm{d}$ in lactation 1 and 1.93 $\mathrm{kg} / \mathrm{d}$ in lactation 2; $P=0.004$ ) and EB (difference LE - HE: $-2.91 \mathrm{Mcal} / \mathrm{d}$ in lactation 1 and $-3.8 \mathrm{Mcal} / \mathrm{d}$ in lactation $2 ; P=0.0001$ ) during the 2 lactations (Table 2 and Figure $3 \mathrm{E}$ and $\mathrm{F}$ ). In both lactations, these 2 parameters increased with time from 4 wkpp $(P<0.0001)$. We also observed a higher DMI (Figure $3 \mathrm{E}$ ) and higher $\mathrm{EB}$ (Figure $3 \mathrm{~F}$ ) in $\mathrm{HE}$ cows than in LE cows.

\section{Fat Thickness and Plasma Fatty Acid, Glucose, and Insulin Concentrations at the Beginning of First and Second Lactations}

To assess mobilization of body reserves, subcutaneous adipose tissue thickness and plasma fatty acid concentrations were measured peripartum during first and second lactation. No effect of the diet was observed on subcutaneous adipose tissue thicknesses determined from -4 to 8 wkpp, whereas year $(P=0.01)$ and week $(P<0.0001)$ effects were significant (Table 2$)$. Plasma fatty acid, glucose, and insulin concentrations were affected by year $(P<0.0001)$ but not by diet (Figure $4 \mathrm{~A}$, $\mathrm{B}$, and $\mathrm{C})$. An effect of week $(P<0.0001)$ was observed 


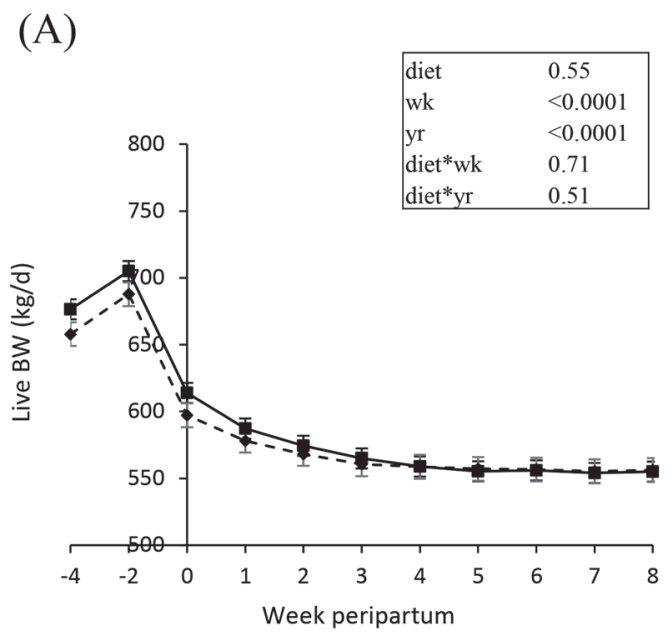

(B)

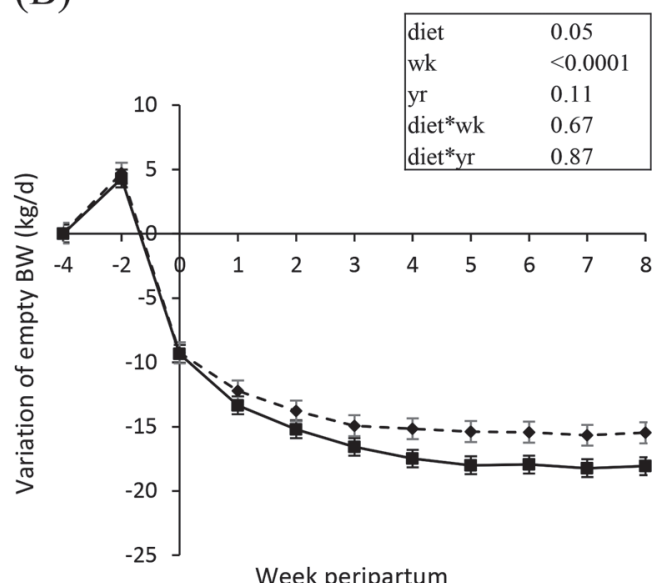

(C)

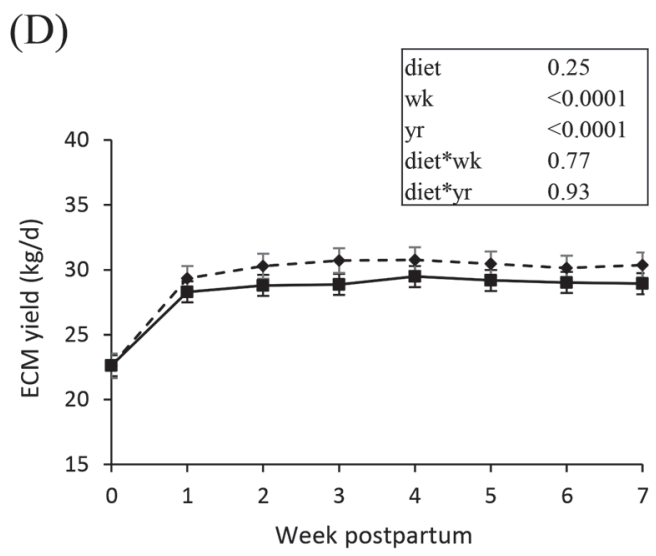

(E)
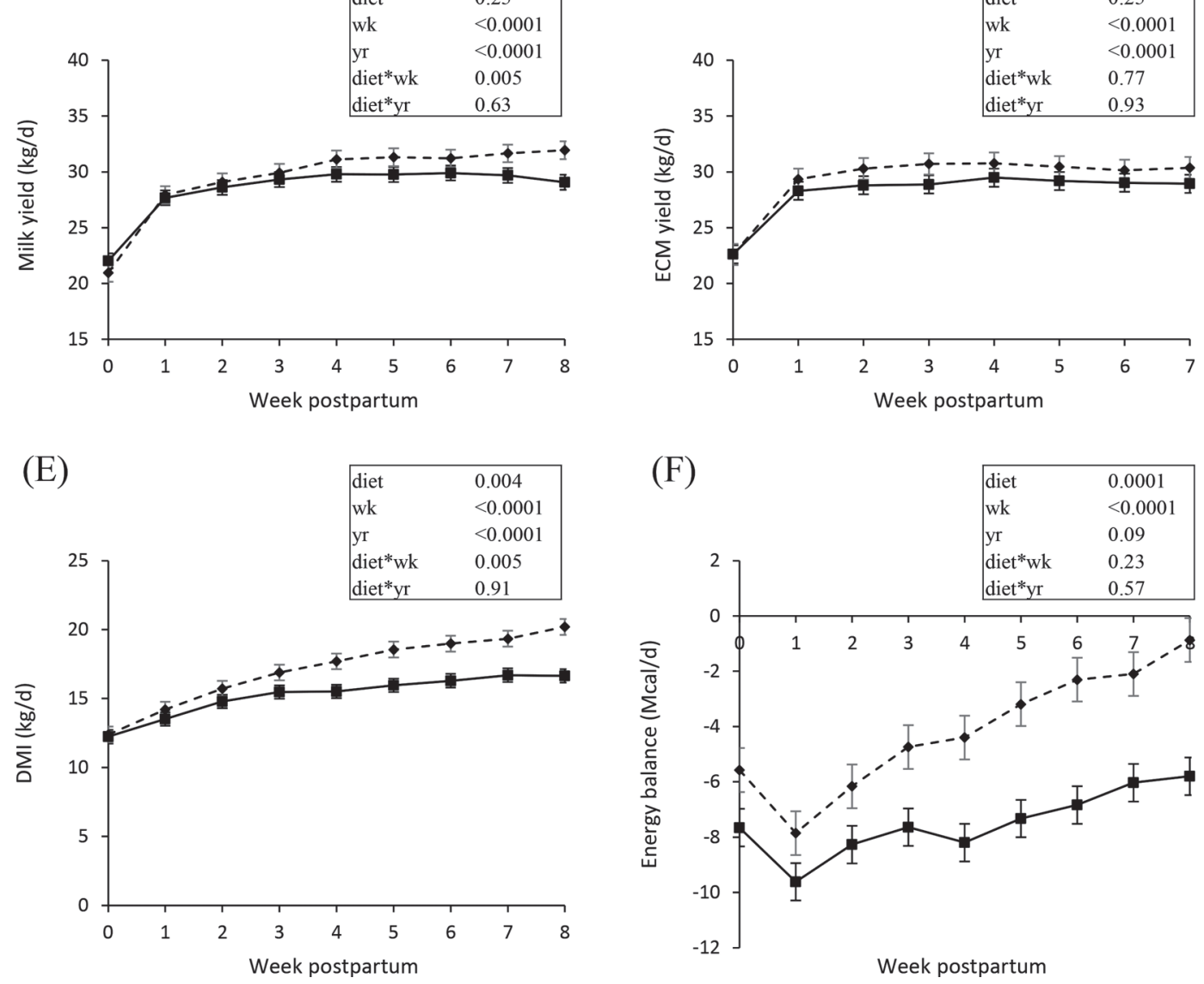

Figure 3. Live BW (A), variation in empty BW (B), milk yield (C), ECM yield (D), DMI (E), and energy balance (F) in primiparous Holstein dairy cows fed either a high-energy (HE) diet or a low-energy (LE) diet between -4 and 8 wk peripartum during the first 2 years of lactation. Results are presented as LSM \pm SEM. $P$-values of diet, week, year, and the interaction between diet and week or year effect are presented.

for plasma fatty acid and insulin concentrations but not for glucose. Plasma fatty acid concentration increased after calving and then decreased gradually during lac- tation in both HE and LE cows (Figure 4A). Finally, plasma insulin concentrations decreased before calving and increased slightly after calving (Figure 4C). 


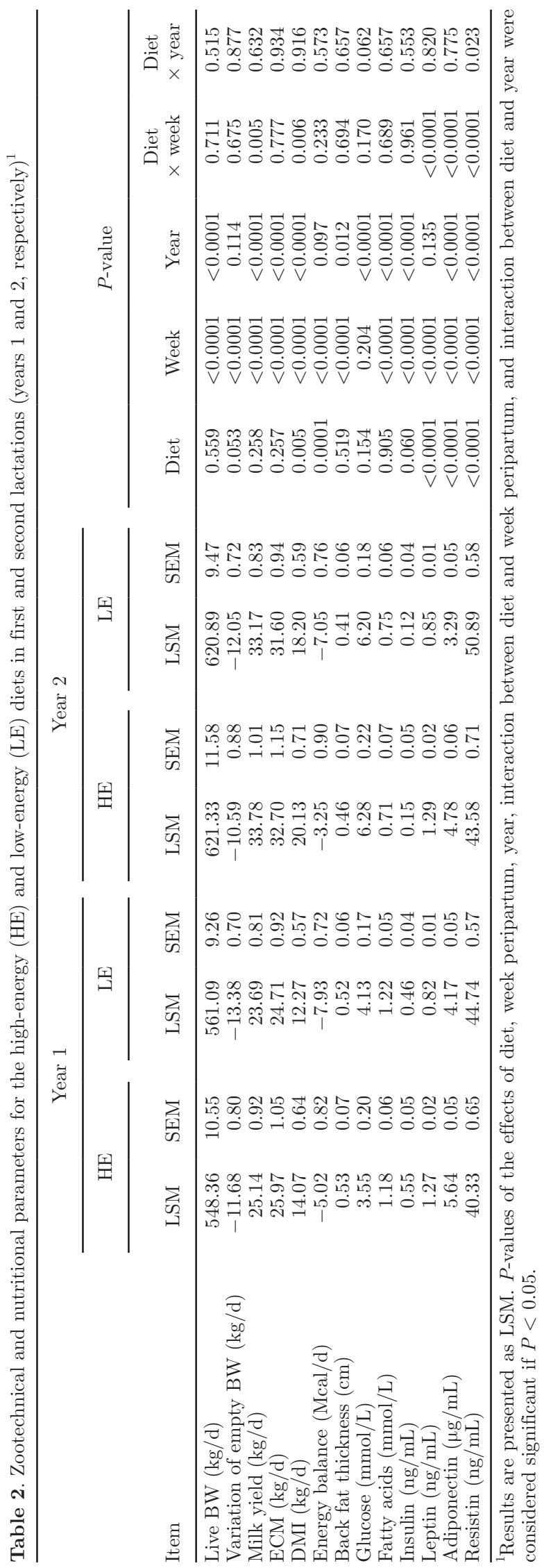

\section{Plasma Concentrations of Adipokines at the Beginning of First and Second Lactations and Association with Other Metabolic Parameters}

Plasma concentrations of leptin, adiponectin, and resistin were affected by diet, year (except for plasma leptin concentration), and week $(P \leq 0.0001$; Figure $4 \mathrm{D}$, $\mathrm{E}$ and F, Table 2). Plasma leptin (Figure 4D) and adiponectin (Figure 4E) concentrations decreased before calving and then increased progressively throughout lactation. Higher concentrations of these 2 adipokines were found in HE cows than in LE cows during first and second lactations. In contrast, plasma resistin concentrations increased before calving and decreased after calving. Lower concentrations of resistin were found in HE cows than in LE cows during the 2 first lactations (Figure 4F).

As shown in Table 3, plasma fatty acid levels were negatively correlated with $\mathrm{EB}(\mathrm{r}=-0.19, P=0.055)$ and plasma adiponectin concentrations were positively correlated with DMI $(\mathrm{r}=0.36, P=0.0003)$, but also with MY $(\mathrm{r}=0.20, P=0.044)$ and $\mathrm{EB}(\mathrm{r}=0.21, P=$ $0.035)$. They were also negatively correlated with resistin $(\mathrm{r}=-0.76, P<0.0001)$ and positively correlated with leptin $(\mathrm{r}=0.30, P=0.003)$ plasma concentrations. Unlike adiponectin, plasma resistin concentrations were positively correlated with back fat thickness $(\mathrm{r}=0.33$, $P=0.001)$ and plasma fatty acid concentrations $(\mathrm{r}=$ $0.23, P=0.021)$ and negatively correlated with DMI (r $=-0.31, P=0.002), \mathrm{MY}(\mathrm{r}=-0.22, P=0.027)$, and plasma leptin concentrations $(\mathrm{r}=-0.29, P=0.004)$.

\section{Ovarian Activity During the Cycle Before Al in Primiparous Dairy Cows}

The length of the estrus cycle was not significantly different between $\mathrm{HE}$ and LE cows $(25.6 \pm 2.2 \mathrm{~d}$ vs. $28.4 \pm 2.7 \mathrm{~d}$, respectively). We observed that 3 -wave cycles were more frequent in $\mathrm{HE}$ cows than in LE cows (HE: $41.2 \%$, vs. LE: $13.6 \%, P=0.0002$, Table 4). No significant differences were found when analyzing other numbers of follicular waves or thresholds for this number (Table 4). We found that the number of SF, $\mathrm{MF}$, and LF was not affected by diet (Figure 5A). No significant difference in $\mathrm{AMH}$ concentration was found between the 2 diets (HE: $98 \pm 25 \mathrm{ng} / \mathrm{mL}$ vs. LE: $80 \pm$ $18 \mathrm{ng} / \mathrm{mL}$; Figure 5B).

\section{Reproductive Parameters and Association with Plasma Adipokine Concentrations}

Postpartum C-LA after first calving occurred significantly earlier in HE than in LE animals $(24.5 \pm 2.2$ vs. $33.3 \pm 3.3 \mathrm{~d} ; P=0.02)$. However, after second calving, 

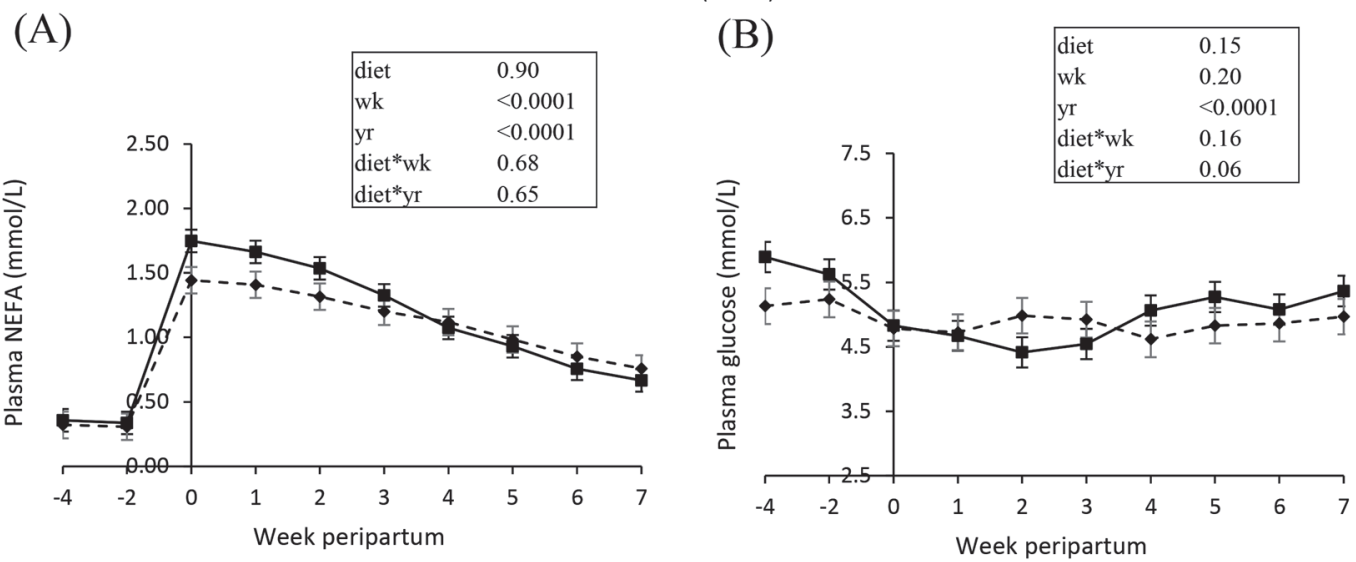

(C)

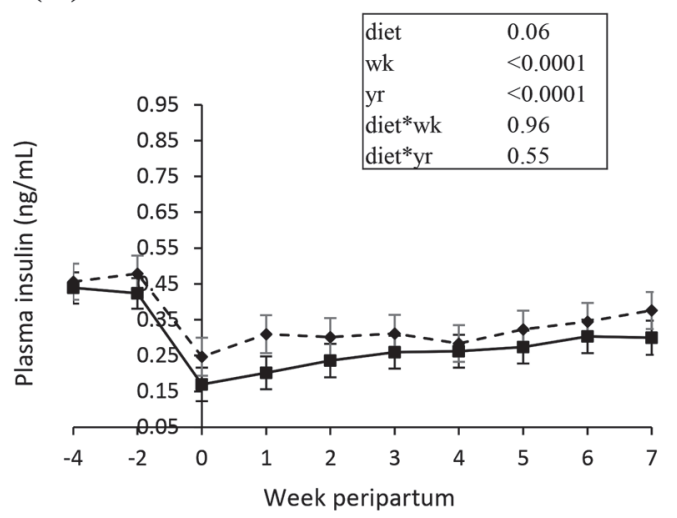

(D)
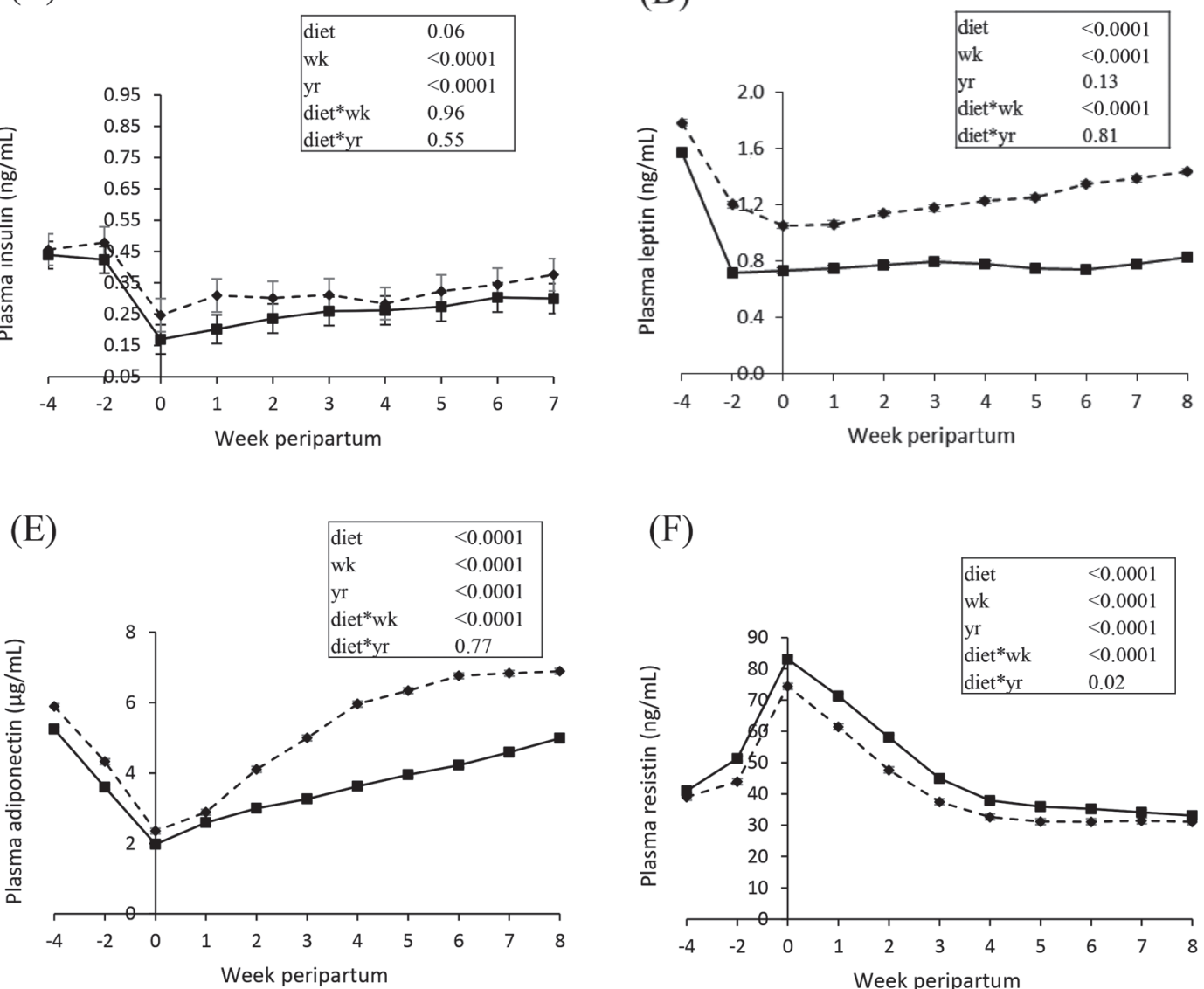

Figure 4. Plasma concentrations of (A) fatty acids (NEFA), (B) glucose, (C) insulin, (D) leptin, (E) adiponectin, and (F) resistin in primiparous Holstein dairy cows fed either a high-energy (HE) diet or a low-energy (LE) diet between -4 and 8 wk peripartum during the first 2 years of lactation. Blood samples were collected weekly before the morning diet distribution. Results are presented as LSM \pm SEM. $P$-values of diet, week, year, and the interaction between diet and week or year effect are presented.

C-LA did not differ between HE and LE animals (28.6 \pm 3.7 vs. $30.4 \pm 3.4 \mathrm{~d} ; P=0.30)$. Conception rates did not differ between the 2 diet groups at $35 \mathrm{~d}$ (HE: $35.3 \%$, LE: $40.9 \% ; P=0.98$ ) or $90 \mathrm{~d}$ after AI (HE:
29.4\%, LE: $40.9 \%, P=0.72$; Table 5). However, the interval between first and second calving tended to increase in LE cows compared with HE cows (HE: 378 d, LE: $415 \mathrm{~d} ; P=0.12)$. No difference between diet groups 
Table 3. Pearson correlation coefficients (r) calculated between plasma adipokine levels (adiponectin, resistin, and leptin) and plasma fatty acid levels and metabolic parameters ${ }^{1}$

\begin{tabular}{llcccc}
\hline Item & & Fatty acids & Leptin & Adiponectin & Resistin \\
\hline DMI & $\mathrm{r}$ & 0.11 & $\mathbf{0 . 2 3}$ & $\mathbf{0 . 3 6}$ & $-\mathbf{0 . 3 1}$ \\
& $P$-value & 0.285 & $\mathbf{0 . 0 2 3}$ & $\mathbf{0 . 0 0 0 3}$ & $\mathbf{0 . 0 0 2}$ \\
Energy balance & $\mathrm{r}$ & $-\mathbf{0 . 1 9}$ & 0.18 & $\mathbf{0 . 2 1}$ & -0.17 \\
& $P$-value & $\mathbf{0 . 0 5 5}$ & 0.081 & $\mathbf{0 . 0 3 5}$ & 0.094 \\
Milk yield & $\mathrm{r}$ & $\mathbf{0 . 3 8}$ & 0.10 & $\mathbf{0 . 2 0}$ & $-\mathbf{0 . 2 2}$ \\
& $P$-value & $\mathbf{0 . 0 0 0 1}$ & 0.318 & $\mathbf{0 . 0 4 4}$ & $\mathbf{0 . 0 2 7}$ \\
Back fat thickness & $\mathrm{r}$ & $\mathbf{0 . 2 8}$ & -0.05 & $\mathbf{- 0 . 3 7}$ & $\mathbf{0 . 3 3}$ \\
& $P$-value & $\mathbf{0 . 0 0 5}$ & 0.597 & $\mathbf{0 . 0 0 0 1}$ & $\mathbf{0 . 0 0 1}$ \\
Glucose & $\mathrm{r}$ & -0.13 & 0.14 & -0.04 & -0.02 \\
Insulin & $P$-value & 0.197 & 0.153 & 0.723 & 0.846 \\
& $\mathrm{r}$ & 0.001 & -0.07 & -0.14 & 0.05 \\
Fatty acids & $P$-value & 0.995 & 0.493 & 0.161 & 0.590 \\
& $\mathrm{r}$ & & 0.03 & -0.16 & $\mathbf{0 . 2 3}$ \\
Leptin & $P$-value & & 0.763 & 0.106 & $\mathbf{0 . 0 2 1}$ \\
Adiponectin & $\mathrm{r}$ & & & $\mathbf{0 . 3 0}$ & $-\mathbf{0 . 2 9}$ \\
& $P$-value & & & $\mathbf{0 . 0 0 3}$ & $\mathbf{0 . 0 0 4}$ \\
& $\mathrm{r}$ & & & & $\mathbf{0 . 7 6}$ \\
& $P$-value & & & & $<\mathbf{0 . 0 0 0 1}$ \\
\hline
\end{tabular}

${ }^{1}$ Values of $\mathrm{r}$ and significance of correlations are indicated in the table. Correlations were considered as significant if $P<0.05$; bold indicates significant correlations.

was found for the interval between calving and first AI (HE: $70 \mathrm{~d}$ vs. LE: $80 \mathrm{~d} ; P=0.18$, Table 5).

As shown in Table 6, we observed a significant positive correlation between the number of follicles $(\mathrm{SF}$, $\mathrm{MF}$, and $\mathrm{LF}$ ) and the AUC of plasma resistin concentrations (SF: $\mathrm{r}=0.46, P=0.05 ; \mathrm{MF}: \mathrm{r}=0.45, P$ $=0.051 ; \mathrm{LF}: \mathrm{r}=0.45, P=0.055)$. Furthermore, the number of SF was positively correlated with the nadir of plasma resistin concentration $(\mathrm{r}=0.45, P=0.053)$.

\section{LH Pulsatility During the Follicular Phase and Preovulatory Surge}

Figure $6 \mathrm{~A}$ shows representative $\mathrm{LH}$ profiles of $\mathrm{HE}$ and LE animals. Basal LH concentrations did not differ significantly between LE and HE cows (1.01 \pm 0.1 vs. $0.9 \pm 0.1 \mathrm{ng} / \mathrm{mL}$ ). However, the mean pulse frequency was higher in HE cows $(7.4 \pm 0.3$ pulses per $6 \mathrm{~h})$ than in LE cows $(6.5 \pm 0.2$ pulses per $6 \mathrm{~h} ; P=0.03$, Figure $6 \mathrm{~B})$. No effect of the diet was observed on the magnitude (HE: $5.9 \pm 0.6$ vs. LE: $5.7 \pm 0.5 \mathrm{ng} / \mathrm{mL} ; P=0.81$ ) or duration of the LH surge (HE: $10.5 \pm 2.2 \mathrm{~h}$ vs. LE: $11.1 \pm 1.9 \mathrm{~h} ; P=0.74)$.

\section{DISCUSSION}

In cows from the LE and HE groups, the severity of NEB after calving correlated with greater concentrations of plasma fatty acids, indicating a high mobilization of body reserves and increasing DMI and MY as previously described (Gross et al., 2011). In addition, we observed that LE cows lost more weight (VEBW), resulting in a more pronounced and persistent NEB than that in HE cows. However, the effect of diet on NEB was not associated with differences in plasma fatty acid concentrations or back fat thickness. This suggests that no difference in fat mobilization existed between the 2 groups of animals despite the effect of diet on adipokine concentrations. Most studies mention that the mobilization of body reserves to satisfy energy needs depends on environmental and genetic factors (Friggens et al., 2004). Within the range of differences created by

Table 4. Percentage (number of animals/total) of cows fed a high-energy diet (HE) or low-energy (LE) diet studied by ovarian ultrasonographic examination during the cycle before AI with $0,1,2,3$, or $\geq 4$ waves

\begin{tabular}{lccccc}
\hline \multicolumn{5}{c}{ Number of follicular waves per cycle } \\
\cline { 2 - 6 } Item & 0 & 1 & 2 & 3 & $\geq 4$ \\
\hline HE diet & $5.9(1 / 17)$ & $11.8(2 / 17)$ & $11.8(2 / 17)$ & $41.2(7 / 17)$ & $29.4(5 / 17)$ \\
LE diet & $13.6(3 / 22)$ & $18.2(4 / 22)$ & $18.2(4 / 22)$ & $13.6(3 / 22)$ & $36.4(8 / 22)$ \\
$P$-value & 0.08 & 0.24 & 0.24 & 0.0002 & 0.39 \\
Total & $10.3(4 / 39)$ & $15.4(6 / 39)$ & $15.4(6 / 39)$ & $25.6(10 / 39)$ & $33.3(13 / 39)$ \\
\hline
\end{tabular}


Table 5. Success rate (\%; pregnant female/total) to first service at 35 and $90 \mathrm{~d}$, and calving-to-calving and calving-to-AI intervals (means $\pm \mathrm{SEM}$ ) in cows fed a high-energy (HE) or low-energy (LE) diet

\begin{tabular}{lccl}
\hline & \multicolumn{2}{c}{ Group } & \\
\cline { 2 - 3 } Item & HE & LE & $P$-value \\
\hline Days after AI & & & \\
$35 \mathrm{~d}$ & $35.3(6 / 17)$ & $40.9(9 / 22)$ & NS $(P=0.98)$ \\
$90 \mathrm{~d}$ & $29.4(5 / 17)$ & $40.9(9 / 22)$ & NS $(P=0.72)$ \\
Calving-calving (d) & $377.8 \pm 16.3$ & $415.4 \pm 18.5$ & NS $(P=0.12)$ \\
Calving-AI (d) & $69.6 \pm 5.4$ & $79.6 \pm 6.0$ & NS $(P=0.18)$ \\
\hline
\end{tabular}

the diets applied here, our data suggest that adipose tissue mobilization is independent of nutrition and depends more on genetics. Concentrations of plasma leptin, adiponectin, and resistin were related to NEB status (Sadri et al., 2011; Giesy et al., 2012; Reverchon et al., 2014b) and clear links with the control of re-
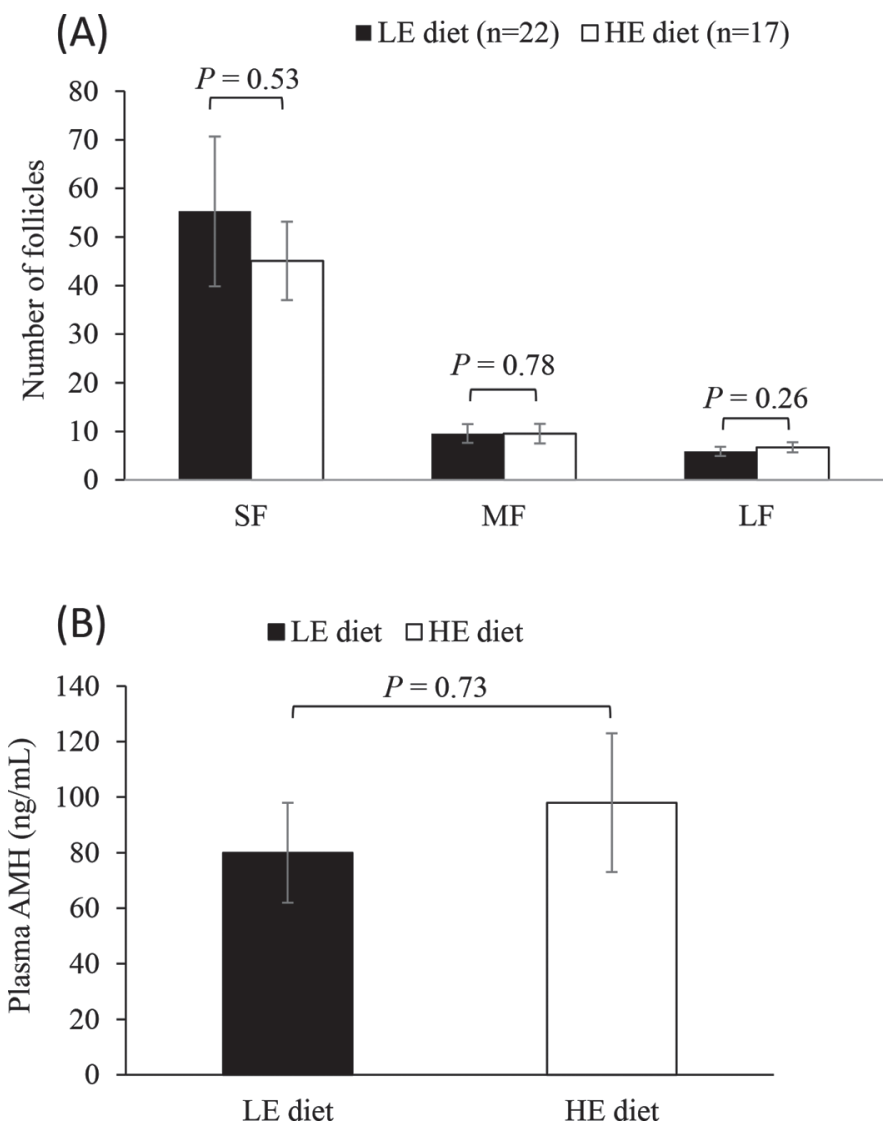

Figure 5. Mean number of small (SF), medium (MF), and large (LF) follicles per animal (A) and plasma concentration of anti-müllerian hormone (AMH; B) of primiparous Holstein dairy cows fed either a high-energy (HE) diet or a low-energy (LE) diet. Thirty-nine heifers were monitored during the cycle before AI, and follicles were classified according to their antral size: small $(3-5 \mathrm{~mm})$, medium $(>5$ and $\leq 7$ $\mathrm{mm})$ and large follicles $(>7 \mathrm{~mm})$. Results are represented as LSM \pm SEM. productive function have been reported (Kadokawa et al., 2000; Liefers et al., 2003; Reverchon et al., 2014a). Our results confirm that the most prominent changes in plasma adipokines occur around calving (Giesy et al., 2012; Ohtani et al., 2012; Singh et al., 2014; De Koster et al., 2017). Leptin concentrations decline to a nadir at parturition and decrease rapidly during periods of undernutrition (Delavaud et al., 2002). Reduced leptin concentrations have been associated with delayed resumption of ovarian cyclicity (Kadokawa et al., 2000; Liefers et al., 2003). Changes in resistin concentrations in the present study, showing an increase after calving and positive correlation with fatty acids, are consistent with previously published results from our group (Reverchon et al., 2014b). Similarly, positive correlations between fatty acids and resistin have been reported in dairy cows (Weber et al., 2016) and during early lactation in dairy goats (Guzel and Belenli, 2015). The existence of these relationships suggests that in dairy ruminants, resistin may contribute to the regulation of lipolysis during the peripartum period. Previous data showing that recombinant bovine resistin increases the release of glycerol and mRNA levels for adipose triglyceride lipase and hormone-sensitive lipase in dairy cow adipose tissue explants (Reverchon et al., 2014b) also support the former hypothesis that resistin contributes to regulation of lipolysis. In the present study, postpartum plasma resistin was higher in LE than in HE animals, suggesting that plasma resistin could be regulated by diet. The decline in adiponectin concentrations prepartum and the increase postpartum are consistent with profiles previously described in dairy cows. As documented for resistin, differences in adiponectin concentrations between HE and LE groups have not been reported before and suggest possible control of their production or secretion by diet. Back fat thickness (measured by ultrasonography) gives an accurate measure of fat reserves in cows (Singh et al., 2015). The negative correlation between adiponectin concentration and back fat thickness found in the present study confirms earlier results in overconditioned cows (Locher et al., 2015) that also showed also a negative correlation 
between expression of adiponectin in subcutaneous adipose tissue and BCS, but this negative relationship was not revealed during the dry period (De Koster et al., 2017).

Several authors have reported unfavorable effects of NEB on reproductive efficiency in dairy cows (Butler and Smith, 1989; Lucy et al., 1992; Jorritsma et al., 2003). In cattle, NEB has been shown to influence steroid hormone secretion (both progesterone and estradiol), growth rate, and the diameter of the dominant follicle and estrus behavior (for review, see Leroy et al., 2008a). Considering the above information and the fact that LE animals expressed more severe NEB than HE cows, a reduction in reproductive performance in LE animals was expected. However, we found no difference between the 2 diet groups in terms of reproductive efficiency when estimated from pregnancy rates and intercalving interval. In addition, follicular dynamics were very similar between the 2 groups of animals. Savio et al. (1990) and Sartori et al. (2004) reported that several follicular waves were observed during the postpartum period and the only difference observed between diet groups was a higher occurrence of cycles with 3 follicular waves in HE compared with LE animals. It has been suggested that due to a prolonged period of follicular development unfavorable to oocyte maturation, fertility could be lower in cows with 2 waves than in cows with 3 waves (Townson et al., 2002) but if it existed, this effect was not observed here. However, consistent with the earlier observations showing effects of NEB on ovarian activity (Beam and Butler, 1997; Wathes et al., 2007b), luteal activity after first calving occurred ear- lier in HE than in LE cows. Although plasma adipokine concentrations were significantly affected by diet, few relationships were found between them and reproductive parameters. The positive correlation between the AUC of plasma resistin concentration and the number of follicles (of any size) should be explored in further work and it would be interesting to confirm the established link by functional studies. Resistin could regulate ovarian cell proliferation and steroidogenesis and consequently affect follicular development. Indeed, it has been shown that human recombinant resistin increases in vitro basal proliferation of undifferentiated granulosa cells (from small follicles; Maillard et al., 2011) and inhibits those of differentiated granulosa cells (from large follicles; Spicer et al., 2011).

In dairy cows, NEB has been shown also to impair LH pulse frequency after calving (Beam and Butler, 1997; Wathes et al., 2007b), which may result from the inhibition of GnRH secretion. Consistent with the above, our study suggests that the difference in the resumption of ovarian cyclicity observed between LE and HE groups results from reduced pituitary function. Because concentrations of plasma leptin, resistin, and adiponectin are related to NEB status, we speculate that plasma adipokines could regulate $\mathrm{LH}$ pulse frequency and LH preovulatory surge in dairy cows. Indeed, it has been shown that plasma leptin concentration increases in parallel with the increase in LH pulse frequency in sheep (Blache et al., 2000). In rodent and pig, adiponectin may influence female reproductive functions via its in vitro effect on LH and FSH secretion by gonadotrophs (Lu et al., 2008; Kiezun et al., 2014). A recent

Table 6. Pearson correlation coefficients (r) calculated between plasma adipokine levels (adiponectin, resistin, and leptin) and reproductive parameters $^{1}$

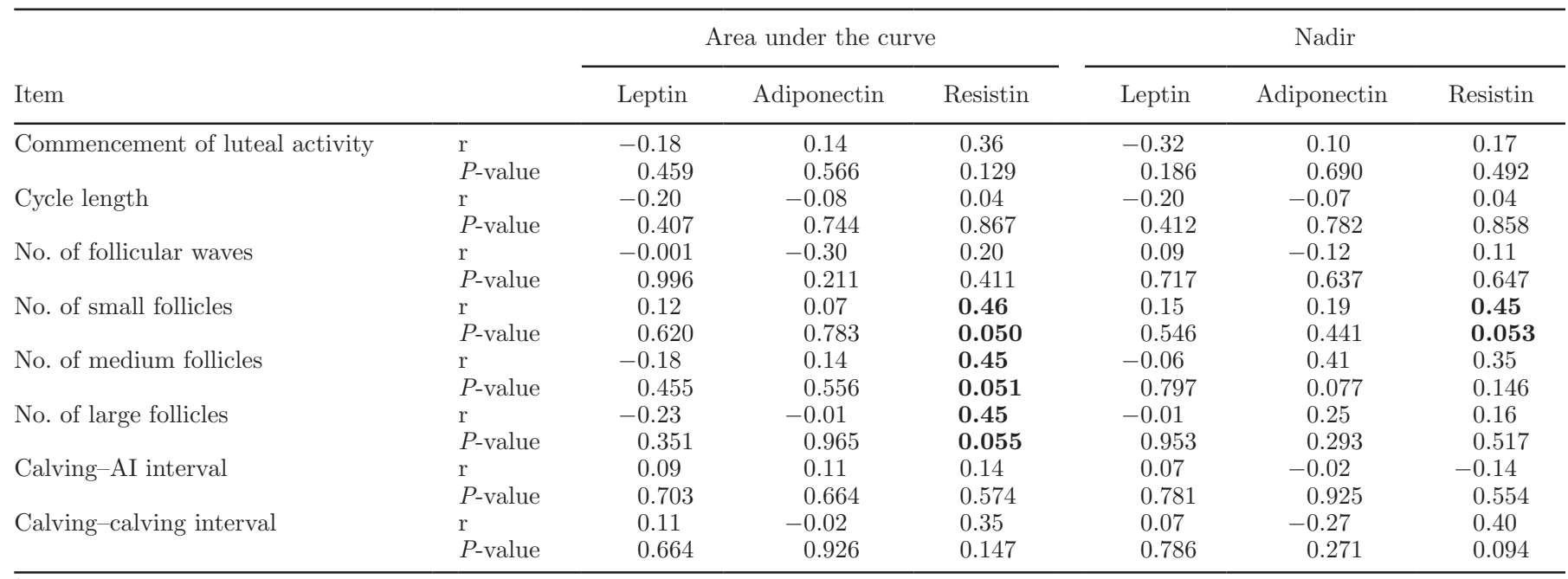

${ }^{1}$ Values of $\mathrm{r}$ and significance of correlations are indicated in the table. Correlations were considered significant if $P<0.05$; bold indicates significant correlations. 


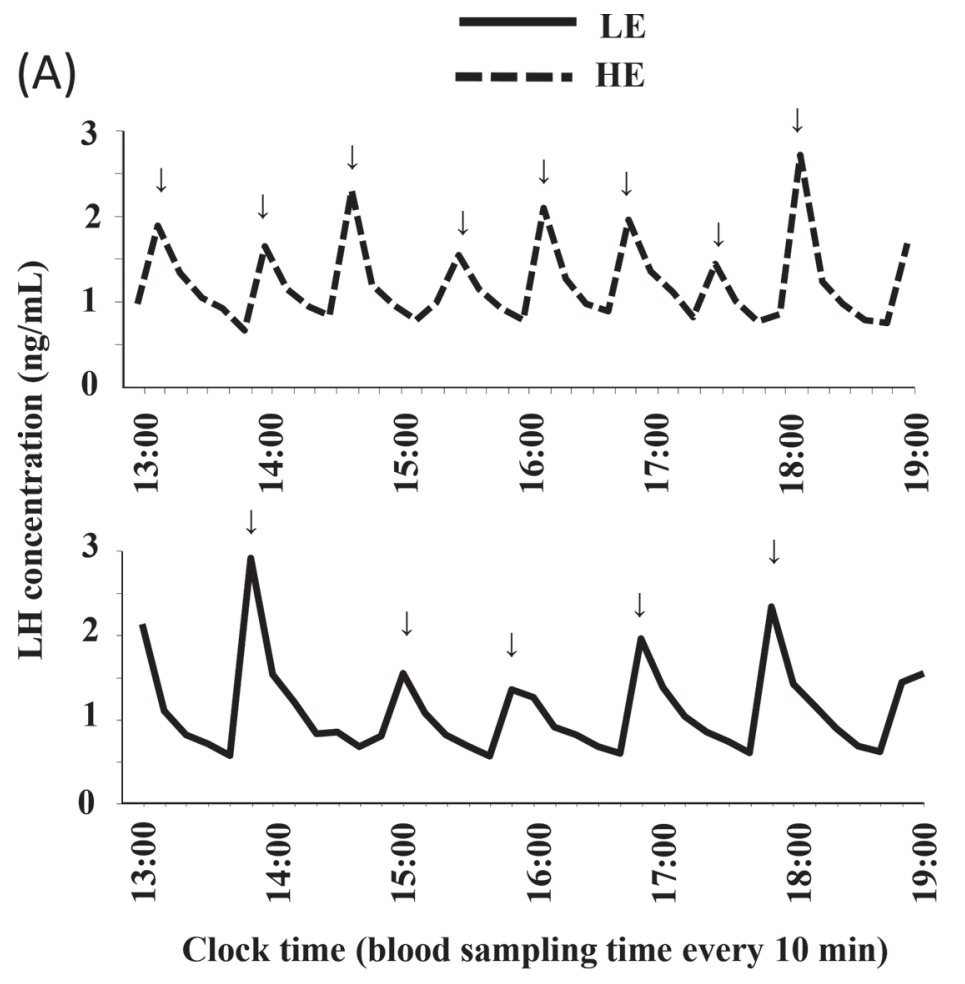

(B)
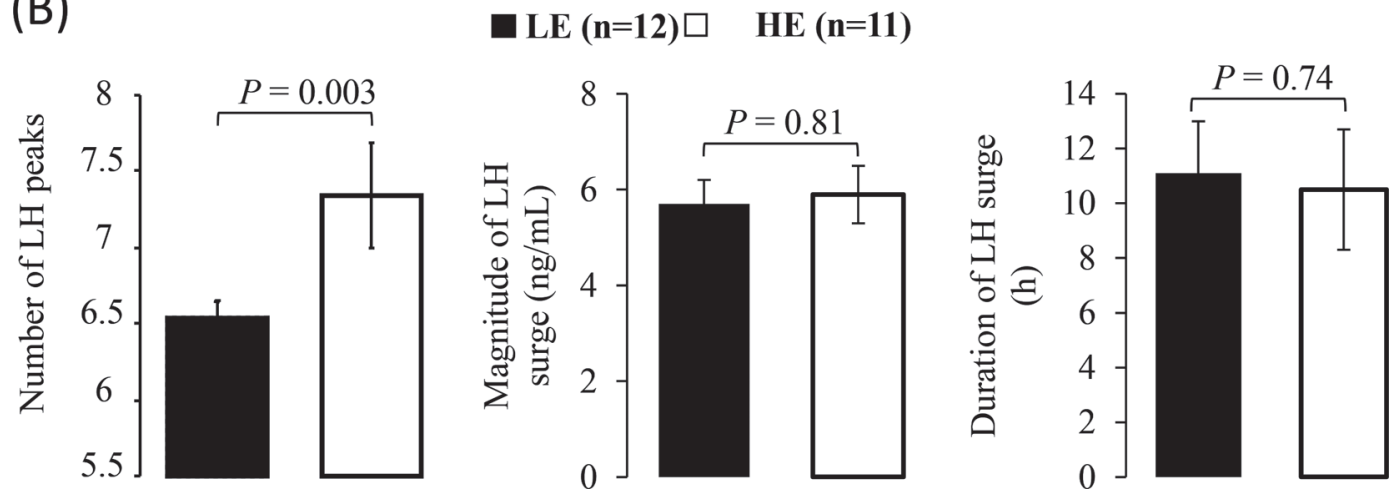

Figure 6. (A) Pulsatility of LH during the follicular phase of the estrous cycle. Representative profiles of LH concentration for one animal of each diet-high-energy (HE) or low-energy (LE) diet animals are shown. Graphs represent blood sampling at 10-min intervals for a 6-h period starting $20 \mathrm{~h}$ after progestagen implant removal. Dashed and solid lines represent pulses automatically detected by the DynPeak algorithm (Vidal et al., 2012), and asterisks indicate LH pulses. (B) Number of LH pulses and magnitude and duration of LH surge during the 6-h period in HE and LE animals. Arrows show LH peaks. Results are represented as LSM \pm SEM.

paper suggests that local or circulating adipokine levels could contribute to the fine regulation of pituitary functions in primates (Sarmento-Cabral et al., 2017). Thus, it would be interesting to determine whether adipokines plasma concentrations are associated with LH pulsatility and LH preovulatory surge in dairy cows. In our study, differences in reproductive function between diets groups were limited to the initiation of ovarian activity and events that took place before first AI. As mentioned above, no effect was found on fertility data. A lack of power to detect differences in reproductive performances could be noted; however, fertility data from the 2 groups were very similar and a trend existed for the decreased performance in the LE group. In earlier studies, negative effects of NEB on reproductive performance were associated with an increase in fatty acid concentrations (Leroy et al., 2008b), which was not observed here. These results are consistent with those of Cutullic et al. (2011), showing that low-level feeding strategies do not disturb reproductive function such that fertility data are affected. It may be hypothesized that the restoration of regular ovarian cyclicity 
together with the decline of fatty acid concentrations occurring at later stages postpartum allows successful pregnancy.

\section{CONCLUSIONS}

The profiles of 3 adipokines (leptin, adiponectin, and resistin) were affected by the energy content of the diet but did not influence fat mobilization. We can hypothesize that the effect of diet on plasma concentrations of adipokines is associated with mechanisms that regulate NEB and maintain fat reserves. The effect of a low-energy diet on reproductive function was limited to re-establishment of ovarian activity and alterations of LH profiles. Weak correlations existed between adipokine profiles and reproductive performance. The association between resistin levels and numbers of growing follicles during the postpartum period deserves further investigations. Taken together, these data suggest that, in the range of differences of energy applied in these experiments, the changes induced by diet, including the modifications of adipokines profiles, influence mechanisms more associated with energy metabolism than fertility.

\section{ACKNOWLEDGMENTS}

The research leading to these results has received funding from the European Union Seventh Framework Programs (FP7:2007-2013) under the grant agreement no. 311776 and from Apis-Gene (Valoprot, Paris, France) for the setup of plasma bovine adiponectin ELISA. We thank Eric Briant, Mickael Dupont, Mickael Delanoue, Ludovic Métivier, and Christophe Mouaze of the Experimental Unit UEPAO for animal management and involvement in the experiment. We also thank Dalbies-Tran Rozen (INRA UMR85 Physiologie de la Reproduction et des Comportements, Nouzilly, France; CNRS UMR7247 Physiologie de la Reproduction et des Comportements, Nouzilly, France; Université François Rabelais de Tours, Tours, France; IFCE, Nouzilly, France) for her helpful discussions. N. Mellouk is a PhD student supported by the Ministère de la Recherche (Ministry of Research).

\section{REFERENCES}

Bauman, D. E., and W. B. Currie. 1980. Partitioning of nutrients during pregnancy and lactation: a review of mechanisms involving homeostasis and homeorhesis. J. Dairy Sci. 63:1514-1529.

Beam, S. W., and W. R. Butler. 1997. Energy balance and ovarian follicle development prior to the first ovulation postpartum in dairy cows receiving three levels of dietary fat. Biol. Reprod. 56:133-142.

Blache, D., R. L. Tellam, L. M. Chagas, M. A. Blackberry, P. E. Vercoe, and G. B. Martin. 2000. Level of nutrition affects leptin concentrations in plasma and cerebrospinal fluid in sheep. J. Endocrinol. 165:625-637.

Butler, W. R. 2000. Nutritional interactions with reproductive performance in dairy cattle. Anim. Reprod. Sci. 60-61:449-457.

Butler, W. R., and R. D. Smith. 1989. Interrelationships between energy balance and postpartum reproductive function in dairy cattle. J. Dairy Sci. 72:767-783.

Canepa, S., A. Laine, A. Bluteau, C. Fagu, C. Flon, and D. Monniaux. 2008. Validation d'une methode immunoenzymatique pour le dosage de la progesterone dans le plasma des ovins et des bovins. Les Cahiers Techniques de L'INRA 64:19-30.

Chappaz, E., M. S. Albornoz, D. Campos, L. Che, M. F. Palin, B. D. Murphy, and V. Bordignon. 2008. Adiponectin enhances in vitro development of swine embryos. Domest. Anim. Endocrinol. $35: 198-207$.

Cheng, L., H. Shi, Y. Jin, X. Li, J. Pan, Y. Lai, Y. Lin, Y. Jin, G. Roy, A. Zhao, and F. Li. 2016. Adiponectin deficiency leads to female subfertility and ovarian dysfunctions in mice. Endocrinology 157:4875-4887.

Coyral-Castel, S., P. Faverdin, C. Rame, S. Freret, D. Guillaume, S. Fritz, and J. Dupont. 2013. Significant differences in fertility between dairy cows selected for one QTL located on bovine chromosome 3 are not attributable to energy balance, although eating behaviour is affected. Animal 7:610-617.

Cutullic, E., L. Delaby, Y. Gallard, and C. Disenhaus. 2011. Dairy cows' reproductive response to feeding level differs according to the reproductive stage and the breed. Animal 5:731-740.

De Koster, J., C. Urh, M. Hostens, W. Van den Broeck, H. Sauerwein, and G. Opsomer. 2017. Relationship between serum adiponectin concentration, body condition score, and peripheral tissue insulin response of dairy cows during the dry period. Domest. Anim. Endocrinol. 59:100-104.

Delavaud, C., A. Ferlay, Y. Faulconnier, F. Bocquier, G. Kann, and Y. Chilliard. 2002. Plasma leptin concentration in adult cattle: Effects of breed, adiposity, feeding level, and meal intake. J. Anim. Sci. 80:1317-1328.

Diskin, M. G., D. R. Mackey, J. F. Roche, and J. M. Sreenan. 2003. Effects of nutrition and metabolic status on circulating hormones and ovarian follicle development in cattle. Anim. Reprod. Sci. $78: 345-370$.

Dobson, H., R. Smith, M. Royal, C. Knight, and I. Sheldon. 2007. The high-producing dairy cow and its reproductive performance. Reprod. Domest. Anim. 42(Suppl. 2):17-23.

Elis, S., S. Coyral-Castel, S. Freret, J. Cognié, A. Desmarchais, A. Fatet, C. Rame, E. Briant, V. Maillard, and J. Dupont. 2013. Expression of adipokine and lipid metabolism genes in adipose tissue of dairy cows differing in a female fertility quantitative trait locus. J. Dairy Sci. 96:7591-7602.

Fenwick, M. A., S. Llewellyn, R. Fitzpatrick, D. A. Kenny, J. J. Murphy, J. Patton, and D. C. Wathes. 2008. Negative energy balance in dairy cows is associated with specific changes in IGF-binding protein expression in the oviduct. Reproduction 135:63-75.

Friggens, N. C., C. Disenhaus, and H. V. Petit. 2010. Nutritional sub-fertility in the dairy cow: Towards improved reproductive management through a better biological understanding. Animal 4:1197-1213.

Friggens, N. C., K. L. Ingvartsen, and G. C. Emmans. 2004. Prediction of body lipid change in pregnancy and lactation. J. Dairy Sci. $87: 988-1000$.

Garnsworthy, P. C., A. Lock, G. E. Mann, K. D. Sinclair, and R. Webb. 2008. Nutrition, metabolism, and fertility in dairy cows: 1 . Dietary energy source and ovarian function. J. Dairy Sci. 91:3814-3823.

Giesy, S. L., B. Yoon, W. B. Currie, J. W. Kim, and Y. R. Boisclair. 2012. Adiponectin deficit during the precarious glucose economy of early lactation in dairy cows. Endocrinology 153:5834-5844.

Gross, J., H. A. van Dorland, R. M. Bruckmaier, and F. J. Schwarz. 2011. Performance and metabolic profile of dairy cows during a lactational and deliberately induced negative energy balance with subsequent realimentation. J. Dairy Sci. 94:1820-1830.

Guzel, S., and D. Belenli. 2015. The interrelationship between resistin and amylin plasma concentrations and their relation to the con- 
centrations of selected reproductive and metabolic hormones and biochemical variables in the early lactation stage of Saanen goats. Rev. Med Vet. (Toulouse) 166:229-233.

INRA. 2007. Alimentation des bovins, ovins et caprins: Besoins des animaux - Valeurs des aliments. Paris, France: Quae editions. R Jarrige, 1989. Ruminant Nutrition: Recommended Allowances and Feed Tables. John Libbey Eurotext, Montrouge, France.

Jorritsma, R., T. Wensing, T. A. Kruip, P. L. Vos, and J. P. Noordhuizen. 2003. Metabolic changes in early lactation and impaired reproductive performance in dairy cows. Vet. Res. 34:11-26.

Kadokawa, H., D. Blache, Y. Yamada, and G. B. Martin. 2000. Relationships between changes in plasma concentrations of leptin before and after parturition and the timing of first post-partum ovulation in high-producing Holstein dairy cows. Reprod. Fertil. Dev. 12:405-411.

Kafi, M., A. Tamadon, and M. Saeb. 2015. The relationship between serum adiponectin and postpartum luteal activity in high-producing dairy cows. Theriogenology 83:1264-1271.

Kiezun, M., N. Smolinska, A. Maleszka, K. Dobrzyn, K. Szeszko, and T. Kaminski. 2014. Adiponectin expression in the porcine pituitary during the estrous cycle and its effect on LH and FSH secretion. Am. J. Physiol. Endocrinol. Metab. 307:E1038-E1046.

Lagaly, D. V., P. Y. Aad, J. A. Grado-Ahuir, L. B. Hulsey, and L. J. Spicer. 2008. Role of adiponectin in regulating ovarian theca and granulosa cell function. Mol. Cell. Endocrinol. 284:38-45.

Leroy, J. L., G. Opsomer, A. Van Soom, I. G. Goovaerts, and P. E. Bols. 2008a. Reduced fertility in high-yielding dairy cows: Are the oocyte and embryo in danger? Part I. The importance of negative energy balance and altered corpus luteum function to the reduction of oocyte and embryo quality in high-yielding dairy cows. Reprod. Domest. Anim. 43:612-622

Leroy, J. L., A. Van Soom, G. Opsomer, and P. E. Bols. 2008b. The consequences of metabolic changes in high-yielding dairy cows on oocyte and embryo quality. Animal 2:1120-1127.

Leroy, J. L., T. Vanholder, G. Opsomer, A. Van Soom, and A. de Kruif. 2006. The in vitro development of bovine oocytes after maturation in glucose and beta-hydroxybutyrate concentrations associated with negative energy balance in dairy cows. Reprod. Domest. Anim. 41:119-123.

Liefers, S. C., R. F. Veerkamp, M. F. te Pas, C. Delavaud, Y. Chilliard, and T. van der Lende. 2003. Leptin concentrations in relation to energy balance, milk yield, intake, live weight, and estrus in dairy cows. J. Dairy Sci. 86:799-807.

Llewellyn, S., R. Fitzpatrick, D. A. Kenny, J. Patton, and D. C. Wathes. 2008. Endometrial expression of the insulin-like growth factor system during uterine involution in the postpartum dairy cow. Domest. Anim. Endocrinol. 34:391-402.

Locher, L., S. Häussler, L. Laubenthal, S. P. Singh, J. Winkler, A. Kinoshita, A. Kenéz, J. Rehage, K. Huber, H. Sauerwein, and S. Dänicke. 2015. Effect of increasing body condition on key regulators of fat metabolism in subcutaneous adipose tissue depot and circulation of nonlactating dairy cows. J. Dairy Sci. 98:1057-1068.

Lu, M., Q. Tang, J. M. Olefsky, P. L. Mellon, and N. J. Webster. 2008. Adiponectin activates adenosine monophosphate-activated protein kinase and decreases luteinizing hormone secretion in LbetaT2 gonadotropes. Mol. Endocrinol. 22:760-710.

Lucy, M. C. 2001. Reproductive loss in high-producing dairy cattle: Where will it end? J. Dairy Sci. 84:1277-1293.

Lucy, M. C., J. Beck, C. R. Staples, H. H. Head, R. L. De La Sota, and W. W. Thatcher. 1992. Follicular dynamics, plasma metabolites, hormones and insulin-like growth factor I (IGF-I) in lactating cows with positive or negative energy balance during the preovulatory period. Reprod. Nutr. Dev. 32:331-341.

Madeja, Z. E., E. Warzych, J. Peippo, D. Lechniak, and M. Switonski. 2009. Gene expression and protein distribution of leptin and its receptor in bovine oocytes and preattachment embryos produced in vitro. Animal 3:568-578.

Maillard, V., P. Froment, C. Ramé, S. Uzbekova, S. Elis, and J. Dupont. 2011. Expression and effect of resistin on bovine and rat granulosa cell steroidogenesis and proliferation. Reproduction 141:467-479.
Maillard, V., S. Uzbekova, F. Guignot, C. Perreau, C. Ramé, S. Coyral-Castel, and J. Dupont. 2010. Effect of adiponectin on bovine granulosa cell steroidogenesis, oocyte maturation and embryo development. Reprod. Biol. Endocrinol. 8:23.

Montgomery, G. W., G. B. Martin, and J. Pelletier. 1985. Changes in pulsatile LH secretion after ovariectomy in Ile-de-France ewes in two seasons. J. Reprod. Fertil. 73:173-183.

Ntallaris, T., P. Humblot, R. Bäge, Y. Sjunnesson, J. Dupont, and B. Berglund. 2017. Effect of energy balance profiles on metabolic and reproductive response in Holstein and Swedish Red cows. Theriogenology 90:276-283.

Ohtani, Y., T. Takahashi, K. Sato, A. Ardiyanti, S. H. Song, R. Sato, K. Onda, Y. Wada, Y. Obara, K. Suzuki, A. Hagino, S. G. Roh, and K. Katoh. 2012. Changes in circulating adiponectin and metabolic hormone concentrations during periparturient and lactation periods in Holstein dairy cows. Anim. Sci. J. 83:788-795.

Pelletier, J., G. Kann, J. Dolais, and G. Rosselin. 1968. (Radio-immunologic determination of plasma lutenizing hormone in sheep. Comparison with the biologic determination of $\mathrm{LH}$ by the diminution of ovarian ascorbic acid, and example of the application to measure of the blood LH in ewes). C. R. Acad. Sci. Hebd. Seances Acad. Sci. D 266:2352-2354. [in French]

Rémond, B. 1988. Changes in rumen contents over the 1st months of lactation in dairy cows. Reprod. Nutr. Dev. 28:109-111.

Reverchon, M., C. Rame, M. Bertoldo, and J. Dupont. 2014a. Adipokines and the female reproductive tract. Int. J. Endocrinol. 2014:232454.

Reverchon, M., C. Rame, J. Cognie, E. Briant, S. Elis, D. Guillaume, and J. Dupont. 2014b. Resistin in dairy cows: Plasma concentrations during early lactation, expression and potential role in adipose tissue. PLoS One 9:e93198.

Richards, J. S., Z. Liu, T. Kawai, K. Tabata, H. Watanabe, D. Suresh, F. T. Kuo, M. D. Pisarska, and M. Shimada. 2012. Adiponectin and its receptors modulate granulosa cell and cumulus cell functions, fertility, and early embryo development in the mouse and human. Fertil. Steril. 98:471-479.e1.

Royal, M., G. E. Mann, and A. P. Flint. 2000. Strategies for reversing the trend towards subfertility in dairy cattle. Vet. J. 160:53-60.

Sadri, H., M. Mielenz, I. Morel, R. M. Bruckmaier, and H. A. van Dorland. 2011. Plasma leptin and mRNA expression of lipogenesis and lipolysis-related factors in bovine adipose tissue around parturition. J. Anim. Physiol. Anim. Nutr. (Berl.) 95:790-797.

Salazar-Ortiz, J., S. Camous, C. Briant, L. Lardic, D. Chesneau, and D. Guillaume. 2011. Effects of nutritional cues on the duration of the winter anovulatory phase and on associated 3 hormone levels in adult female Welsh pony horses (Equus caballus). Reprod. Biol. Endocrinol. 9:130.

Sarmento-Cabral, A., J. R. Peinado, L. C. Halliday, M. M. Malagon, J. P. Castaño, R. D. Kineman, and R. M. Luque. 2017. Adipokines (leptin, adiponectin, resistin) differentially regulate all hormonal cell types in primary anterior pituitary cell cultures from two primate species. Sci. Rep. 7:43537.

Sartori, R., J. M. Haughian, R. D. Shaver, G. J. Rosa, and M. C. Wiltbank. 2004. Comparison of ovarian function and circulating steroids in estrous cycles of Holstein heifers and lactating cows. J. Dairy Sci. 87:905-920.

Savio, J. D., M. P. Boland, and J. F. Roche. 1990. Development of dominant follicles and length of ovarian cycles in post-partum dairy cows. J. Reprod. Fertil. 88:581-591.

Schröder, U. J., and R. Staufenbiel. 2006. Invited review: Methods to determine body fat reserves in the dairy cow with special regard to ultrasonographic measurement of backfat thickness. J. Dairy Sci. 89:1-14.

Singh, R., S. N. Randhawa, and C. S. Randhawa. 2015. Body condition score and its correlation with ultrasonographic back fat thickness in transition crossbred cows. Vet. World 8:290-294.

Singh, S. P., S. Haussler, J. J. Gross, F. J. Schwarz, R. M. Bruckmaier and H. Sauerwein. 2014. Short communication: circulating and milk adiponectin change differently during energy deficiency at different stages of lactation in dairy cows. J. Dairy Sci. 97:1535-1542. 
Sirois, J., and J. E. Fortune. 1988. Ovarian follicular dynamics during the estrous cycle in heifers monitored by real-time ultrasonography. Biol. Reprod. 39:308-317.

Spicer, L. J., C. S. Chamberlain, and C. C. Francisco. 2000. Ovarian action of leptin: effects on insulin-like growth factor-I-stimulated function of granulosa and thecal cells. Endocrine 12:53-59.

Spicer, L. J., N. B. Schreiber, D. V. Lagaly, P. Y. Aad, L. B. Douthit, and J. A. Grado-Ahuir. 2011. Effect of resistin on granulosa and theca cell function in cattle. Anim. Reprod. Sci. 124:19-27.

Townson, D. H., P. C. Tsang, W. R. Butler, M. Frajblat, L. C. Griel Jr., C. J. Johnson, R. A. Milvae, G. M. Niksic, and J. L. Pate. 2002. Relationship of fertility to ovarian follicular waves before breeding in dairy cows. J. Anim. Sci. 80:1053-1058.

Valour, D., I. Hue, S. A. Degrelle, S. Déjean, G. Marot, O. Dubois, G. Germain, P. Humblot, A. A. Ponter, G. Charpigny, and B. Grimard. 2013. Pre- and post-partum mild underfeeding influences gene expression in the reproductive tract of cyclic dairy cows. Reprod. Domest. Anim. 48:484-499.

Vidal, A., Q. Zhang, C. Medigue, S. Fabre, and F. Clement. 2012. DynPeak: An algorithm for pulse detection and frequency analysis in hormonal time series. PLoS One 7:e39001.
Wathes, D. C., N. Bourne, Z. Cheng, G. E. Mann, V. J. Taylor, and M. P. Coffey. 2007a. Multiple correlation analyses of metabolic and endocrine profiles with fertility in primiparous and multiparous cows. J. Dairy Sci. 90:1310-1325.

Wathes, D. C., Z. Cheng, M. A. Fenwick, R. Fitzpatrick, and J. Patton. 2011. Influence of energy balance on the somatotrophic axis and matrix metalloproteinase expression in the endometrium of the postpartum dairy cow. Reproduction 141:269-281.

Wathes, D. C., M. Fenwick, Z. Cheng, N. Bourne, S. Llewellyn, D. G. Morris, D. Kenny, J. Murphy, and R. Fitzpatrick. 2007b. Influence of negative energy balance on cyclicity and fertility in the high producing dairy cow. Theriogenology 68(Suppl. 1):S232-S241.

Weber, M., L. Locher, K. Huber, A. Kenez, J. Rehage, R. Tienken, U. Meyer, S. Danicke, H. Sauerwein, and M. Mielenz. 2016. Longitudinal changes in adipose tissue of dairy cows from late pregnancy to lactation. Part 1: The adipokines apelin and resistin and their relationship to receptors linked with lipolysis. J. Dairy Sci. 99:1549-1559.

Zieba, D. A., M. Amstalden, and G. L. Williams. 2005. Regulatory roles of leptin in reproduction and metabolism: A comparative review. Domest. Anim. Endocrinol. 29:166-185. 